\title{
ACTIVITY OF ETHYL ACETATE EXTRACT FROM Chrysophyllum cainito L. LEAVES IN DECREASING BLOOD SUGAR LEVEL IN MALE WISTAR RATS
}

\author{
${ }^{1}$ Imam Malikul Hadi Arrijal, ${ }^{2}$ Burhan Ma'arif, dan ${ }^{2}$ Arief Suryadinata \\ ${ }^{1}$ Student of Department of Pharmacy, Faculty of Medical and Health Sciences, Maulana Malik Ibrahim State \\ Islamic University \\ Jl. Gajayana No. 50 Malang 65144 \\ ${ }^{2}$ Department of Pharmacy, Faculty of Medical and Health Sciences, Maulana Malik Ibrahim State Islamic \\ University \\ Jl. Gajayana No. 50 Malang 65144 \\ Co-author, email: imammalikulhadiarrijal@gmail.com \\ *Corresponding author, email: burhan.maarif@farmasi.uin-malang.ac.id \\ Co-author, email: arief_drg@yahoo.com
}

\begin{abstract}
The high morbidity or mortality due to diabetes mellitus becomes the world health problem. That fact encourages the study about antidiabetes drugs from natural material especially plants. This study aims to analyze the effect of ethyl acetate extract from Chrysophyllum cainito L. leaves in decreasing of blood sugar level of alloxan-induced male male wistar rats. This research is considered as experimental research with pre and post test randomized controlled group design. The experimental animals in this study were 25 male male wistar rats divided into 5 treatment groups, treatment with $\mathrm{CMC}-\mathrm{Na}$ (negative control), metformin with the dose of $9 \mathrm{mg} / 200 \mathrm{gBW}$ (positive control), and leaves extract C. cainito dose 25; 50; $75 \mathrm{mg} / \mathrm{kgBW}$. All treatment groups had significant decrease of blood sugar levels at 7, 10 and 14 day observations with $p<0.05$. While in the day 3 had insignificant decrease of blood sugar level with $p>0.05$. Every $C$. cainito leaves extract doses group have the ability to decrease sugar blood level better than negative control, but still below positif control. The optimum dose in decreasing sugar blood level in this study is $75 \mathrm{mg} / \mathrm{kg} \mathrm{BW}$.
\end{abstract}

Keywords: Antidiabetic, Blood sugar level, Chrysophyllum cainito L.,

\section{INTRODUCTION}

The high morbidity or mortality due to diabetes mellitus becomes the world health problem [1]. World Health Organization (WHO) data in 2008 shows that there were approximately 180 million people around the world with diabetes, and in 2030, it is predicted that the number will be doubled. In 2000, there were 8.4 million people with diabetes in Indonesia and this rate ranked 4th after India, China, and United States [2]. That number is predicted to raise into 21.3 million in 2030. The increasing number in people with diabetes will increase antidiabetic drugs use in Indonesia [3].

J. Islamic Pharm., an open access journal

ISSN : 2527-6123 
The increase of DM disease from time to time suggest that specific concern towards DM therapy is needed. Chemical or synthetic drugs are still the dominant choice for diabetes patients. Long-term use of chemical or synthetic drugs are sold in high price and can cause adverse side effects. Clinically, long-term use of chemical drugs will cause adverse effects such as hypoglycemia, nausea, vomiting, diarrhea, and liver dysfunction. Those facts suggest that treatment solution is highly needed. This will encourage the inventions of drugs with low price, better effectivity and minimum side effects [1].

Chrysophyllum cainito L. can be found easily in Philippines and Thailand [4]. C. cainito also can be found in Java Island and some low mountain areas. Most of the parts of this plant can be used, including its leaves, fruit, and even its stem. C. cainito can be found easily in East Java and has medical functions [5]. Tannin-contained water extract of $C$. cainito leaves and fruit is widely used as anti-inflammation of laryngitis and pneumonia condition, cure of cancer, angina (chest pain), diabetes, rheumatoid arthritis, chest pain, and indigestion [6, 7].

Several classes of secondary metabolite compounds contained in the ethanol extract of $C$. cainito leaves include saponins, terpenoids, flavonoids and phenolic, but do not contain alkaloids and steroids. Saponin functions to prevent the transport of glucose to the brush border intestinal in the small intestine, the place of glucose absorption. It may disrupt or inhibit absorption of glucose in the small intestine [8]. The sensitivity of insulin receptors can be corrected by flavonoids contained in plants, so that the flavonoids effects can be beneficial in the state of diabetes mellitus. Several studies have suggested that classes of secondary metabolite compounds such as polyphenol compound, e.g. flavonoids in this plant have an important role in providing activity as inhibitors of $\alpha$-glucosidase [1,9].

Traditional medicine which utilizes medicinal plants can be used as an alternative step to overcome diabetes, because this study aims to determine the effectiveness of blood sugar levels decrease using ethyl acetate of $C$. cainito leaves extract in alloxan-induced male male wistar rats.

\section{MATERIAL AND METHOD}

\section{Materials}

C. cainito leaves powder was purchased from Materia Medika Batu, East Java, Indonesia. Male wistar rats, ethyl acetate, alloxan, metformin, glucose stripe test, CMC-Na, $\mathrm{NaCl}$, concentrated $\mathrm{HCl}, \mathrm{Mg}$ powder, and other material were purchased from Department of 
Pharmacy, Faculty of Medical and Health Sciences, Maulana Malik Ibrahim State Islamic University Malang, East Java, Indonesia.

\section{Methods}

\section{Sample Preparation}

The $C$. cainito leaves were sorted, washed, and dried using oven at $40^{\circ} \mathrm{C}$. The leaves then grinded, and $500 \mathrm{~g}$ powder were extracted pusing $2 \mathrm{~L}$ ethyl acetate. The extract then tested about its flavonoid and saponin compounds.

\section{Alloxan Induction}

The rats are fasted for approximately \pm 8 hours, then rats is induced with 32 $\mathrm{mg} / 200 \mathrm{gBW}$ dose of intraperitonium alloxan by positioning rats towards the frontal to get the abdomen view. Alloxan is injected carefully. Alloxan injection is given every 3-4 days until there is an increase in blood glucose level. Rats are prohibited from eating for \pm 8 hours but still given a drink. Then fasting blood sugar level (H0) is measured. Rats is diagnosed as diabetic if fasting blood sugar levels reach $\geq 126 \mathrm{mg} / \mathrm{dL}$. The negative control group is given CMC-Na (K-), the positive control group is given oral antidiabetic drug, metformin $(\mathrm{K}+)$. Test group 1 is given the extraction of ethyl acetate of $C$. cainito leaves with the dose of 25 $\mathrm{mg} / \mathrm{kgBW}$ (P1). Test group 2 is given the extraction of ethyl acetate of $C$. cainito leaves with the dose of $50 \mathrm{mg} / \mathrm{kgBW}(\mathrm{P} 2)$. Test group 3 is given the extraction of ethyl acetate of $C$. cainito leaves with the dose of $75 \mathrm{mg} / \mathrm{kgBW}$ (P3). Treatment is administered once daily for 14 days after diabetes diagnosis, then performed on days 3, 7, 10 and 14.

\section{Measurement of Blood Glucose Level}

Measurement of blood sugar levels is conducted using glucometer. Blood sampling is performed on the tail of the rats that had been shaved to make the blood vessels clearly visible. After that, the rat tail is given $70 \%$ alcohol and cut with a scalpel to form a small wound. Then the blood is contained on glucotest strip. The results obtained from glucometer is the blood glucose level of the rat.

\section{Data analysis}

To see whether or not there was a significant difference in the value of decreased blood glucose levels between treatment and control group, One Way ANOVA is performed. If there is a significant difference, next step is statistical test, then followed by LSD test to see the real difference between treatments. 


\section{RESULTS AND DISCUSSION}

\section{Sample Preparation}

The first step is $C$. cainito leaves harvest, then continue to wet sorting procedure to separate the dirt or other materials such as soil, gravel, grass and stems. After that the leaves are immediately washed. The leaching of $C$. cainito leaves is conducted by running water to remove any residual debris attached on the leaves. The washing process is done briefly. Drying procedure is conducted with the temperature $40^{\circ} \mathrm{C}$ for $\pm 3-4$ hours to reduce the water on the leaves. Decrease in water content can prevent the growth of molds and reduce enzymatic reactions so as to prevent the occurrence of damage to the simplisia. Drying can be done by using an oven with the temperature of $30^{\circ} \mathrm{C}-90^{\circ} \mathrm{C}$. Oven is used for drying procedure because the required time is relatively fast and the heat given is relatively constant $[11,12]$. The next process is grinding dry $C$. cainito leaves simplisia to get a fine powder. Milling is done to minimize the size of dry $C$. cainito leaves simplisia and to facilitate the extraction process. Size reduction here also aims to enlarge the contact between material and solvent during the extraction process. Then, simplisia is stored in a plastic bag in dry place. Avoid direct sunlight to protect the simplisia so as not to damage or change its quality [12, 13].

\section{C. cainito Leaves Extraction}

C. cainito leaves extraction is conducted by maceration method. Extraction process by maceration method produce two layers. The top layer is filtrate containing the active compound while the bottom layer is the residue of simplisia powder. After that, filtration process is done to separate the filtrate with the residue using filter paper, then collected in a separate container. The residue from the first filtration process is re-extracted with each solvent with the amount of $1500 \mathrm{ml}(1.5 \mathrm{~L})$ at the second and third repeating extraction. So, the total amount of ethyl acetate solvent used is $5000 \mathrm{ml}(5 \mathrm{~L})$, in which the process is intended to obtain the active compounds remaining in the residue. Next, the solvent in the collected filtrate is evaporated using rotary evaporator. The extract obtained is blackish in slightly liquid form. In order to obtain dry extract, the viscous extract is put into an oven with a temperature of $40^{\circ} \mathrm{C}$. The obtained dry extract was 15.39 grams. Calculation of yield produced the value of $3,078 \%$.

\section{Flavonoids and Saponin Identification}

Identification process aims to determine the presence or absence of flavonoids and saponins on $C$. cainito leaves. Identification of flavonoids and saponin is done by color test. It 
is conducted in two different ways, namely by the addition of methanol and ethyl acetate as a solvent in the extract and then added 10 drops of concentrated $\mathrm{HCl}$ and approximately $0.1 \mathrm{~g}$ of $\mathrm{Mg}$ powder. Then the mixture is stirred and observed for any changes. From flavonoids test, orange sample is obtained from the addition of methanol and blue color from the addition of ethyl acetate. If there is a change of color to orange, red, or blue, then the sample contains flavonoids. Magnesium and hydrochloric acid react by forming bubbles of $\mathrm{H}_{2}$ gas. While the concentrated $\mathrm{Mg}$ and $\mathrm{HCl}$ metals in this test serve to reduce benzopiron nuclei in flavonoids structure which allow color change. If a plant extract contains flavonoids, flavilium salts will be form with the addition of $\mathrm{Mg}$ and $\mathrm{HCl}[10,14]$. According to [15] the occurrence of color changes in the sample showed that the sample positively contain flavonoids. While on saponin test, the approximately $1 \mathrm{ml}$ sample is put into a test tube and added with $5 \mathrm{ml}$ of aquades and heated, then cooled and shake vigorously. Saponin test shows the result that there is a constant foam in the sample for about 2 minutes. If no foam occurs within 2-4 minutes, then the sample contains saponin compound. The occurrence of foam indicates the presence of glycosides which have the ability to form foam in water that is hydrolyzed into glucose and other compounds [10, 14].

\section{Antidiabetic Activity}

Based on the measurement of blood glucose level on antidiabetic activity test of ethyl acetate extract of C.cainito leaves to the decrease of blood sugar level, the percentage decrease as represented in Table 1. Based on ANOVA One-Way statistical analysis, it is found that blood glucose level in all treatment groups had significantly decreased in 7, 10, and 14-day observations with $\mathrm{p}<0.05$. While on day 3 , all treatment groups showed in significant decrease of blood glucose level which with $\mathrm{p}>0,05$. One-Way ANOVA statistical analysis result is shown in Table 2. LSD Pos Hoc test as follow-up test is performed on the data. The result of LSD Pos Hoc test is shown in Table 3. Based on LSD data analysis on H3, all groups differed significantly with the negative control group, except in the P1 group. While in H7, H10, H14, all groups differed significantly with the negative control group. Therefore, all extracts have antidiabetic activity. This is reinforced by the results of all groups extracts with negative controls that are significantly different, so it can be concluded that all groups extracts have antidiabetic activity. In all dose groups, $C$. cainito leaves extract has the ability to lower blood sugar levels better than the negative control group, but still below metformin in 
lowering blood sugar levels. The optimum dose in lowering blood glucose levels in this study was $75 \mathrm{mg} / \mathrm{kgBW}$.

\section{CONCLUSION}

Ethyl acetate extract of $C$. cainito leaves with dose $25 \mathrm{mg} / \mathrm{kgBW} ; 50 \mathrm{mg} / \mathrm{kgBW}$; and 75 $\mathrm{mg} / \mathrm{kgBW}$ have decreasing effect on blood glucose level in the alloxan-induced male wistar rats. Ethyl acetate extract of $C$. cainito leaves with dose $75 \mathrm{mg} / \mathrm{kgBW}$ is the optimum dose with highest decreasing ability compare to $25 \mathrm{mg} / \mathrm{kgBW}$ and $50 \mathrm{mg} / \mathrm{kgBW}$ doses. However, the effectiveness of three dose group of ethyl acetate extract of $C$. cainito is still below metformin in lowering the blood glucose of alloxan-induced male wistar rats.

\section{REFERENCES}

[1] Marianne, Yuandani, Rosnani. 2011. Antidiabetic Activity From Ethanol Extract Of Kluwih's Leaves (Artocarpus camansi). Jurnal Natural,Vol. 11, No. 2.

[2] Wild, S., Roglic, G., Green, A., Sicree, R., dan King, H. 2004. Global Prevalence of Diabetes:Estimates for year 2000 and Projections for 2030. Journal Diabetes Care. 27 (5): 47-53.

[3] Fitrianingsih, S.P., dan Purwanti, L. 2012. Uji Efek Hipoglikemik Ekstrak Air Kulit Buah Pisang Ambon Putih terhadap Mencit Model Hiperglikemik Galur Swiss Webster. Prosiding SnaPP 2012.

[4] Hermanto, C., Ni Luh Putu Indriani, Sri Hadiati. 2013. Keragaman dan Kekayaan Buah Tropika Nusantara. Badan Penelitian Dan Pengembangan Pertanian Kementerian Pertanian 2013: IAARD Press.

[5] Luo X.D., Basile M.J., Kennelly E.J. 2002. Polyphenolic antioxidants from the fruits of Chrysophyllum cainito L.(Star Apple). Departement of Biologycal Sciences, Lehman Collegeand Graduate Center University of New York. New York.

[6] Morton, J. 1987. Star Apple, in : Morton, J., Fruits of Warm Climates, Miami Florida. 408-410.

[7] Das, A., Badaruddin, B.N., Bhaumik, A. 2010. A Brief Review on Chrysophyllum cainito. Journal of Pharmacognosy and Herbal Formulations. 1, 1, 1-7.

[8] Yoshikawa, Masayuki, Hisashi Matsuda. 2006. Traditional Medicines for Modern Times Antidiabetic Plants: Saponin. CRC Press.

[9] Zuhro, F., Endah Puspitasari, Siti Muslichah, Mochammad Amrun Hidayat. 2016. $\alpha-$ Glucosidase Inhibitor Activity of Ethanol Extract Kenitu Leaves (Chrysophyllum cainito L.). e-Jurnal Pustaka Kesehatan, Vol. 4, No. 1.

[10] Chunaifi, M. dan Tukiran. 2014. Skrining Fitokimia dari Ekstrak Etil Asetat Kulit Batang Tumbuhan Nyiri Batu (Xylocarpus moluccencis). UNESA Journal of Chemistry Vol. 3, No. 3.

[11] Agoes, Goeswin. 2007. Teknologi Bahan Alam. Bandung: Penerbit ITB.

[12] Laksana, Toga. 2010. Pembuatan Simplisia dan Standarisasi Simplisia. Yogyakarta: UGM. 
[13] Harbone, J.B. 1996. Metode Fitokimia Penuntun Cara Modern Menganalisis Tumbuhan. Padmawinata K, Soediro I, penerjemah. Terjemahan dari: Phytochemical Methods. Bandung: ITB Press.

[14] Marliana, Soerya D., Venty Suryanti, Suyono. 2005. Skrining Fitokimia dan Analisis Kromatografi Lapis Tipis Komponen Kimia Buah Labu Siam (Sechium edule Jacq. Swartz.) dalam Ekstrak Etanol. Biofarmasi 3 (1): 26-31, ISSN: 1693-2242.

[15] Taher, Tamrin. 2011. Identifikasi Senyawa Flavonoid dari Ekstrak Metanol Kulit Batang Langsat (Lansium domesticum L). Skripsi. Gorontalo: UNG.

Table 1. Data of Decreased Blood Sugar Levels

\begin{tabular}{ccccc}
\hline Group & $\mathrm{H} 3$ & $\mathrm{H} 7$ & $\mathrm{H} 10$ & $\mathrm{H} 14$ \\
\hline $\mathrm{K}-$ & $+0,10 \%$ & $+25,70 \%$ & $+33,41 \%$ & $+50,01 \%$ \\
$\mathrm{~K}+$ & $-0,27 \%$ & $-35,41 \%$ & $-46,79 \%$ & $-73,15 \%$ \\
P1 & $-0,25 \%$ & $-25,70 \%$ & $-31,08 \%$ & $-34,67 \%$ \\
P2 & $-0,22 \%$ & $-32,79 \%$ & $-40,91 \%$ & $-46,88 \%$ \\
P3 & $-0,28 \%$ & $-36,34 \%$ & $-45,86 \%$ & $-66,59 \%$ \\
\hline
\end{tabular}

Table 2. One-way ANOVA Test Results

\begin{tabular}{ccccccc}
\hline \multirow{2}{*}{ Variable } & \multicolumn{5}{c}{ Average Decrease in Blood Sugar Levels } & \multirow{2}{*}{ Sig. } \\
\cline { 2 - 6 } & $\mathrm{K}(-)$ & $\mathrm{K}(+)$ & $\mathrm{P} 1$ & $\mathrm{P} 2$ & $\mathrm{P} 3$ & \\
\hline H3 & $0,3 \pm 0,6$ & $-1,3 \pm 1,2$ & $-1,0 \pm 0,0$ & $-1,0 \pm 1,0$ & $-1,3 \pm 0,6$ & 0,120 \\
H7 & $72,3 \pm 41,2$ & $-169,3 \pm 48,5$ & $-102,3 \pm 16,6$ & $-146,7 \pm 34,5$ & $-164,3 \pm 16,3$ & 0,000 \\
H10 & $94,0 \pm 26,9$ & $-223,7 \pm 49,5$ & $-123,7 \pm 10,4$ & $-183,0 \pm 7,0$ & $-207,3 \pm 24,9$ & 0,000 \\
H14 & $140,7 \pm 47,4$ & $-349,7 \pm 32,3$ & $-138,0 \pm 16,1$ & $-209,7 \pm 18,6$ & $-301,0 \pm 59,4$ & 0,000 \\
\hline
\end{tabular}


Table 3. Post Hoc LSD Test Results

\begin{tabular}{|c|c|c|c|c|c|c|}
\hline $\begin{array}{c}\text { Observation } \\
\text { Time }\end{array}$ & Treatment & $\mathrm{K}(-)$ & $\mathrm{K}(+)$ & P1 & $\mathrm{P} 2$ & P3 \\
\hline \multirow[t]{5}{*}{ H3 } & $\mathrm{K}(-)$ & & $0,025^{*}$ & 0,061 & $0,025^{*}$ & $0,025^{*}$ \\
\hline & $\mathrm{K}(+)$ & $0,025^{*}$ & & 0,610 & 0,610 & 1,000 \\
\hline & $\mathrm{P} 1$ & 0,061 & 0,610 & & 1,000 & 0,610 \\
\hline & $\mathrm{P} 2$ & $0,025^{*}$ & 0,610 & 1,000 & & 0,610 \\
\hline & P3 & $0,025^{*}$ & 1,000 & 0,610 & 0,610 & \\
\hline \multirow[t]{5}{*}{$\mathrm{H7}$} & $\mathrm{K}(-)$ & & $0,000^{*}$ & $0,000^{*}$ & $0,000^{*}$ & $0,000^{*}$ \\
\hline & $\mathrm{K}(+)$ & $0,000 *$ & & 0,037 * & 0,433 & 0,861 \\
\hline & $\mathrm{P} 1$ & $0,000 *$ & $0,037 *$ & & 0,141 & $0,050^{*}$ \\
\hline & $\mathrm{P} 2$ & $0,000 *$ & 0,433 & 0,141 & & 0,539 \\
\hline & P3 & $0,000 *$ & 0,861 & $0,050 *$ & 0,539 & \\
\hline \multirow[t]{5}{*}{ H10 } & $\mathrm{K}(-)$ & & $0,000 *$ & $0,000^{*}$ & $0,000^{*}$ & $0,000^{*}$ \\
\hline & $\mathrm{K}(+)$ & $0,000 *$ & & $0,001 *$ & 0,107 & 0,493 \\
\hline & $\mathrm{P} 1$ & $0,000^{*}$ & $0,001^{*}$ & & $0,027^{*}$ & $0,005^{*}$ \\
\hline & $\mathrm{P} 2$ & $0,000 *$ & 0,107 & $0,027 *$ & & 0,314 \\
\hline & P3 & $0,000^{*}$ & 0,493 & $0,005^{*}$ & 0,314 & \\
\hline \multirow[t]{5}{*}{ H14 } & $\mathrm{K}(-)$ & & $0,000 *$ & $0,000 *$ & $0,000^{*}$ & $0,000^{*}$ \\
\hline & $\mathrm{K}(+)$ & $0,000 *$ & & $0,000^{*}$ & $0,001 *$ & 0,153 \\
\hline & $\mathrm{P} 1$ & $0,000 *$ & $0,000^{*}$ & & $0,046^{*}$ & $0,000^{*}$ \\
\hline & $\mathrm{P} 2$ & $0,000 *$ & $0,001^{*}$ & $0,046^{*}$ & & $0,016^{*}$ \\
\hline & P3 & $0,000 *$ & 0,153 & $0,000 *$ & $0,016^{*}$ & \\
\hline
\end{tabular}

* Significant Data $\mathrm{p}<0,05$ 